University of Wollongong

Research Online

Faculty of Law - Papers (Archive)

Faculty of Business and Law

$1-1-2009$

\title{
Charting a sustainable course through changing Arctic waters
}

Robin Warner

University of Wollongong, rwarner@uow.edu.au

Follow this and additional works at: https://ro.uow.edu.au/lawpapers

Part of the Law Commons

\section{Recommended Citation}

Warner, Robin: Charting a sustainable course through changing Arctic waters 2009, 323-348.

https://ro.uow.edu.au/lawpapers/78

Research Online is the open access institutional repository for the University of Wollongong. For further information contact the UOW Library: research-pubs@uow.edu.au 


\title{
Charting a sustainable course through changing Arctic waters
}

\begin{abstract}
As the Arctic ice recedes, the opportunities for all year round routing of merchant shipping through Arctic waters rise. The freeing up of Arctic waters may also attract increased numbers of scientific research vessels servicing oil and gas installations, foreign fishing vessels and warships. The prospect of major navigational channels opening up in this region brings risks to a pristine Arcti environment and its indigenous inhabitants. This article highlights the threats posed to the species, habitats and ecosystems of Arctic waters from increased shipping transits of the region including the potential for increased vessel source discharges of noxious and hazardous substances and the catastrophic consequences of groundings for the Arctic environment and its biodiversity. It reviews the legal controversies over the status of certain parts of Arctic waters and the navigational regimes applicable to foreign flag vessels transiting Arctic waters under the 1982 United Nations Law of the Sea Convention (LOSC). The need to balance navigational rights with appropriate environmental safeguards under an increasing array of international environmental principles including the precautionary approach and obligations to assess the impact of ship based activities on the global environment and its marine components is examined. The article then analyses some of the regulatory mechanisms which have been devised to promote environmentally sustainable navigation for shipping in sensitive areas of ocean space subject to high levels of shipping traffic through the International Maritime Organization (IMO).
\end{abstract}

\section{Keywords}

charting, sustainable, changing, course, waters, arctic

Disciplines

Law

Publication Details

Warner, R. (2009). Charting a sustainable course through changing Arctic waters. Yearbook of Polar Law, $1323-348$. 


\title{
Charting a Sustainable Course through Changing Arctic Waters
}

\author{
Robin Warner*
}

\section{Abstract}

As the Arctic ice recedes, the opportunities for all year round routing of merchant shipping through Arctic waters rise. The freeing up of Arctic waters may also attract increased numbers of scientific research vessels, vessels servicing oil and gas installations, foreign fishing vessels and warships. The prospect of major navigational channels opening up in this region bring risks to a pristine Arctic environment and its indigenous inhabitants. This article highlights the threats posed to the species, habitats and ecosystems of Arctic waters from increased shipping transits of the region including the potential for increased vessel source discharges of noxious and hazardous substances and the catastrophic consequences of groundings for the Arctic environment and its biodiversity. It reviews the legal controversies over the status of certain parts of Arctic waters and the navigational regimes applicable to foreign flag vessels transiting Arctic waters under the 1982 United Nations Law of the Sea Convention (LOSC). The need to balance navigational rights with appropriate environmental safeguards under an increasing array of international environmental principles including the precautionary approach and obligations to assess the impact of ship based activities on the global environment and its marine components is examined. The article then analyses some of the regulatory mechanisms which have been devised to promote environmentally sustainable navigation for shipping in sensitive areas of ocean space subject to high levels of shipping traffic through the International Maritime Organisation (IMO).

\footnotetext{
* Senior Research Fellow, Australian National Centre for Ocean Resources and Security, University of Wollongong, Australia. Email: rwarner@uow.edu.au.
} 


\section{Introduction}

The sea routes across the top of the world through Arctic waters and often impenetrable sea ice have held an enduring attraction for adventurous voyagers and scientific expeditions over decades and more recently nuclear submarine deployments. ${ }^{1}$ As the planet warms and the Arctic sea ice recedes, the lure of these routes will become even more irresistible for a whole new cadre of vessels including commercial shipping, scientific research vessels, vessels servicing oil and gas installations, fishing vessels and warships. ${ }^{2}$ The prospect of major navigational channels opening up in Arctic waters bring risks as well as opportunities to this remote part of the globe, its unique marine environment, marine resources and indigenous inhabitants. ${ }^{3}$ This article highlights the threats posed to the species, habitats and ecosystems of Arctic waters from a higher volume of shipping transits of the region including the potential for increased vessel source discharges of harmful substances, the transfer of alien species into the fragile Arctic environment and the catastrophic consequences of ship casualties for the marine environment and its biodiversity. It reviews the legal controversies over the status of certain parts of Arctic waters and the navigational regimes applicable to foreign flag vessels transiting these waters under the 1982 United Nations Law of the Sea Convention (LOSC). ${ }^{4}$ The unilateral powers of coastal States to regulate foreign shipping transits which occur in waters under their jurisdiction are also examined.

In addition to navigational regimes under the LOSC, vessels transiting Arctic waters are subject to an increasing array of international environmental law principles which are based on precautionary standards and developed procedures for assessing the impact of activities on the global environment and its marine components. The need to balance navigational rights with appropriate environmental safeguards under these principles will become

\footnotetext{
${ }^{1}$ William E. Butler, Northeast Arctic Passage (Alphen aan den Rijn, The Netherlands: Sijthoff \& Noordhoff, 1978), 1.

2 Oystein Jensen, "Arctic shipping guidelines: towards a legal regime for navigation safety and environmental protection?" Polar Record 44 (229) (2008): 108; Robert W. Corell, "Challenges of Climate Change: An Arctic Perspective" Ambio 35(4) (June 2006): 151; Rob Huebert and Brooks B. Yeager, A new sea. The need for a regional agreement on management and conservation of the Arctic Marine Environment (Oslo: WWF International Arctic Programme: 2008), 12.

3 Jensen, above n. 2, 107-108; James Kraska, "The Law of the Sea Convention and the Northwest Passage" The International Journal of Marine and Coastal Law 22(2) (2007): 258259; Rosemary Rayfuse, "Protecting Marine Biodiversity in Polar Areas Beyond National Jurisdiction” RECIEL 17(1) (2008): 6.

${ }^{4}$ United Nations Convention on the Law of the Sea, opened for signature 10 December 1982, 1833 UNTS 3 (entered into force 16 November 1994) (LOSC).
} 
critical as ship based activities increase in Arctic waters. ${ }^{5}$ As with other strategically and economically significant waterways around the world such as the Straits of Malacca and the Torres Strait, user States guaranteed access to these waters through the medium of passage rights under the LOSC have also assumed commensurate responsibilities under international law to protect and preserve the marine environment and its biodiversity through tailored ships routing measures. ${ }^{6}$ This article analyses some of the regulatory mechanisms which have been devised to achieve this balance for commercial shipping in a globally acceptable manner through the International Maritime Organisation (IMO) and State practice in implementing ships routing measures which are designed to promote environmentally sustainable navigation in sensitive areas of ocean space subject to high levels of shipping traffic. Comparable situations in other regions of the world where ships routing measures have been introduced to strike a complementary balance between navigational rights and environmental protection concerns may offer some insight into reconciling these two bodies of international law in a workable framework for Arctic waters as global shipping transits increase. Finally the article argues that the duty of States to cooperate in the protection and preservation of the Arctic marine environment from the adverse impacts of increased shipping and the urgent need to develop environmental protection measures to achieve that objective should not be delayed by the intractability of sovereignty disputes over the key ocean passages in question.

\section{The Potential Impacts of Increased Shipping Transits in Arctic Waters}

'Arctic waters' have been defined as all those marine and estuarine waters north of 60 degrees north latitude. ${ }^{7}$ Within Arctic waters the focus of debate

\footnotetext{
${ }^{5}$ Neil Craik, "Presumed Innocent: Navigation Rights and Risk-based Activities in the Passamaquoddy Bay” University of New Brunswick Law Journal 58 (2008): 170 comments that "the procedural obligations of international environmental law provide an opportunity for a more cooperative and contextually sensitive approach to resolving disputes involving risk based activities... in essence the rules relating to innocent passage forsake contextual sensitivity in favour of legal certainty, while the rules in relation to transboundary environmental harm call for much greater consideration of the respective rights and interests of the parties. Taken together, the rules retain overall coherence by allowing source (flag) states to undertake unilateral activities, but only after satisfying onerous procedural obligations of risk evaluation and good faith consultation."

${ }^{6}$ Kraska, above n. 3, 279-281.

${ }^{7}$ National Oceanographic Administration (NOAA), Glossary, http://www.nfms.noaa.gov/pr/ glossary.htm (accessed 6 August 2008): Rosemary Rayfuse, "Melting Moments: The future
} 
on increased shipping transits has centred on the North West passage and the Northern Sea route, formerly known as the North East Passage. ${ }^{8}$ There have also been suggestions that with the melting of the Arctic sea ice, routes further from the coasts of the Arctic States through what is now the central polar ice cap could open up for shipping. ${ }^{9}$ The North West passage is a set of alternative sea routes connecting Europe and the Atlantic Ocean with Asia and the Pacific Ocean passing through interconnecting waters in the northern part of the North American continent through the Canadian coastal archipelago and along the north coast of Alaska. ${ }^{10}$ The Northern Sea Route is the route along the Russian coasts of the Far East and Siberia which also connects the Atlantic and Pacific Oceans. ${ }^{11}$ The particular attraction of the North West passage and Northern Sea Route is that they involve a much shorter transit time for ships travelling between Europe and Asia than routes through the Panama Canal or around Cape Horn. ${ }^{12}$ The current sea ice coverage of parts of these routes for several months during the year limits their viability as commercial shipping routes. ${ }^{13}$ In the past transit of these routes was infrequent and mainly conducted by purpose built icebreakers on government service for scientific research and re-supply purposes and military vessels although some commercial ships used the routes. ${ }^{14}$ Navigation in the Arctic has diversified in recent years now encompassing commercial and fishing vessels, vessels engaged in offshore exploration and passenger ships. ${ }^{15}$

The marine environment in and around these sea routes has a number of important characteristics which make its protection and preservation critical for both the local inhabitants and the global environment. Many of the species, habitats and ecosystems of the Arctic contribute significantly to

of polar oceans governance in a warming world" RECIEL 16(2) (2007): 210 reviews other definitions of the Arctic region.

${ }^{8}$ Kraska, above n. 3, 258; Jensen, above n. 2, 108; Tavis Potts and Clive Schofield, "Current Legal Developments. The Arctic" The International Journal of Marine and Coastal Law 23(1) (2008): 176.

${ }^{9}$ Potts et al., above n. 8, 176.

${ }^{10}$ Jensen, above n. 2, 108; Kraska, above n. 3, 258.

${ }^{11}$ Donald R. Rothwell, The Polar Regions and the Development of International Law (Cambridge: Cambridge University Press, 1996), 201; Butler, above n. 1, 54.

${ }^{12}$ Kraska, above n. 3, 258; Donat Pharand, "The Arctic Waters and the Northwest Passage: A Final Revisit" Ocean Development and International Law 38(1) (2007): 3; Potts et al., above n. 8, 156-157.

${ }^{13}$ Jensen, above n. 2, 107.

${ }^{14}$ Ibid.

${ }^{15}$ Ibid., 108. 
global biodiversity as they are found nowhere else on the planet. ${ }^{16}$ They are uniquely adapted to that region and highly sensitive to changes in environmental conditions. ${ }^{17}$ The predicted rapid melting of the sea ice cover as the planet warms will have both positive and negative effects for Arctic species. The Arctic hosts a substantial proportion of the world's total global production of fisheries. ${ }^{18}$ As the sea ice melts fish species adapted to the current conditions may move north and eventually decline while other fish species from warmer waters may move north. ${ }^{19}$ Drastic changes and loss of habitat are predicted for Arctic marine mammals such as the walrus, polar bear, ringed seals and Arctic cetaceans which are dependent on ice conditions for survival..$^{20}$ The dependence of indigenous inhabitants of the Arctic on their local marine resources is still high with profoundly negative impacts being predicted for future human health and food security of these communities as these resources decline. ${ }^{21}$ The integral connection of the Arctic to other parts of the globe through ocean and air currents and migratory species will also ensure that rapid changes in its marine environment are likely to have widespread effects on global oceans and species distribution. ${ }^{22}$

Both the Intergovernmental Panel on Climate Change (IPCC) and the Arctic Climate Impact Assessment commissioned by the Arctic Council in 2006 have found that reduced sea ice is very likely to increase marine transport and access to resources in the Arctic. ${ }^{23}$ Increases in marine transport activities in Arctic waters will compound the effects of climate change on the marine environment with a further array of shipping impacts which have the potential to harm the marine environment. A higher volume of vessel traffic will result in a concomitant rise in accidental and intentional discharges of harmful substances such as oily wastes, sewage, garbage, hazardous and noxious materials and atmospheric emissions of gases such as sulfur dioxide. ${ }^{24}$ The risk of groundings, collisions, fires and ship strikes of marine mammals will escalate particularly in areas where some ice still exists as will the noise

\footnotetext{
${ }^{16}$ Andrew Clarke and Colin M. Harris, "Polar marine ecosystems; major threats and future change" Environmental Conservation 30 2003: 10; Lynne Rosentrater and Aynslie E. Ogden, "Building Resilience in Arctic Ecosystems" in Buying Time: A Users Manual, ed. L.J. Hansen, J.L. Biringer and J.R. Hoffman (Oslo: WWF International Arctic Programme: 2006), 96.

${ }_{17}$ Rosentrater et al., above n. 16, 96; Rayfuse, above n. 3, 4.

${ }^{18}$ Rosentrater et al., above n. 16, 96.

19 Rosentrater et al., above n. 16, 103-104.

${ }^{20}$ Clarke et al., above n. 16, 10; Rosentrater et al., above n. 16, 104-105; Corell, above n. 2, 150.

${ }^{21}$ Corell, above n. 2, 151; Clarke et al., above n. 16, 10.

${ }^{22}$ Corell, above n. 2, 150; Rosentrater et al., above n. 16, 97.

${ }^{23}$ Corell, above n. 2, 151.

${ }^{24}$ Rosentrater et al., above n. 16, 98-99; Clarke et al., above n. 16, 12.
} 
generated by regular shipping transits in a previously pristine environment. ${ }^{25}$ The exchange of ballast water in the high seas areas of Arctic shipping routes has the potential to introduce organisms and pathogens which are alien to the Arctic marine environment and likely to overrun populations of endemic organisms. ${ }^{26}$ As resource exploitation activities for oil and gas intensify, the associated vessel and drilling activities are likely to have deleterious effects on slow growing Arctic marine species, their habitats and ecosystems. ${ }^{27}$

While the magnitude of increased shipping transits of ice reduced Arctic waters cannot be predicted with certainty at this stage, the Arctic Council has commissioned the Arctic Marine Shipping Assessment (AMSA) to conduct some assessments of current and future marine activity in Arctic waters including marine navigation. ${ }^{28}$ Two scenario creation and analysis workshops on the Future of Arctic Marine Navigation in 2050 held in 2007 as apart of this assessment produced four possible scenarios based on two uncertainty axes, the degree of governance stability both within the Arctic region and internationally and the level of demand for Arctic resources and trade. ${ }^{29}$ At one end of the governance axis less stability implied deficiencies in legal and regulatory structures and a tendency for actors to work unilaterally rather than in a collaborative, multilateral manner..$^{30}$ The other end of the governance axis postulated more stability with efficient and transparent legal and regulatory structures and a global and regional environment favourable to cooperative endeavour between actors and stakeholders. ${ }^{31}$ At one end of the resources and trade axis, less demand implied that fewer actors were interested in Arctic resources while the other end of the resources and trade axis was characterised by higher demand from more global actors and markets for Arctic resources and transhipment routes through Arctic waters. ${ }^{32}$

Consideration of both axes resulted in the positing of four scenarios for Arctic marine navigation in 2050. The Arctic Race scenario was characterised by high demand for Arctic resources and trade and less stable governance. The impacts of this scenario for marine navigation in the Arctic included

${ }^{25}$ Ibid.

${ }^{26}$ Rosentrater et al., above n. 16, 99.

${ }^{27}$ Clarke, above n. 16, 12; Corell, above n. 2, 151.

${ }^{28}$ A. Tucci. "Oil Spill Response and the Challenges of Arctic Marine Shipping: An Assessment by the Arctic Council” in Oil Spill Response; A Global Perspective ed. W.F. Davidson, K. Lee and A. Cogswell (Dordrecht: Springer Netherlands, 2008), 3.

29 Protection of the Arctic Marine Environment (PAME), Arctic Marine Shipping Assessment: Scenarios of the Future <http:www.pame.is>, 24 August 2008.

${ }^{30}$ Ibid.

${ }^{31}$ Ibid.

${ }^{32}$ Ibid. 
higher military vessel activity and an increased presence of resource exploitation vessels which remained in the Arctic for longer periods. Arctic States tended to have inconsistent legal and regulatory structures applicable to vessels navigating in Arctic waters and seasonal trans-Arctic passage although navigationally possible was not permitted politically. ${ }^{33}$ The Polar Lows scenario was characterised by less demand for Arctic resources and trade and less stable governance. This scenario is brought on by a global economic downturn and States focusing on domestic rather than global issues and less rapid melting of the Arctic sea ice. The implications of this scenario for Arctic navigation included minimal Arctic marine traffic, predominantly government re-supply vessels and research vessels, and low attention to legal and regulatory frameworks governing navigation with inconsistent standards among the Arctic States and lack of enforcement against non compliant vessels. ${ }^{34}$ The Polar Preserve scenario was characterised by less demand for Arctic resources and trade and more stable governance in the region. In this climate of slow Arctic development concern for the environment achieves some prominence and an extensive eco preserve is established with stringent no shipping zones. Arctic States agree on harmonised rules for Arctic ship design and pollution prevention, however, seasonal trans-Arctic shipping although possible proves prohibitively expensive due to environmental restrictions, frequent patrols and aggressive enforcement by the Arctic States. ${ }^{35}$ A fourth scenario, Arctic Saga, is characterised by more demand for Arctic resources and trade and more stable governance. A combination of factors including expanded global economic prosperity and shared economic and political interests among the Arctic States spawn a wide range and variety of marine activity. As a result, navigational infrastructure and aids are expanded and developments in technology such as marine surveillance systems make seasonal trans-Arctic shipping safer and more environmentally sustainable. ${ }^{36}$ While none of these scenarios is likely to provide an exact forecast of the future of Arctic marine navigation and its potential to impact on the marine environment, they do highlight the need to consider in advance how the current legal and regulatory structure for Arctic marine navigation can be enhanced to mitigate the adverse impacts of increased shipping on the Arctic marine environment.

\footnotetext{
${ }^{33}$ Global Business Network, The Future of Arctic Marine Navigation in Mid-Century (May 2008) <http:www.pame.is>, (accessed 24 August 2008), 7.

${ }^{34}$ Ibid., 10.

${ }^{35}$ Ibid., 13.

${ }^{36}$ Ibid., 16.
} 


\section{Current Regulatory Structure for Arctic Marine Navigation}

The passage rights of foreign flag vessels in the offshore waters of the Arctic States is determined by the status of those waters under the LOSC and customary international law. ${ }^{37}$ One of the key achievements of the LOSC was to create more certainty in relation to coastal States claims to offshore zones and the navigational regimes applicable to foreign flag vessels transiting those zones. The initial delineation of coastal State baselines and delimitation of offshore zones between opposite and adjacent States, however, often remains a matter of contention between States which complicates the analysis of passage rights in specific areas. The Arctic Ocean is surrounded by littoral States with claims to territorial seas, exclusive economic zones or exclusive fishery zones and continental shelves which extend towards the North Pole leaving a relatively small area of high seas and seabed beyond national jurisdiction in Arctic waters. ${ }^{38}$ Notwithstanding the array of claims which have been made by Arctic States to offshore areas, there are still outstanding issues as to the location of internal waters, positioning of coastal State baselines, delimitation lines between opposite and adjacent states and the extent of coastal States extended continental shelf claims in the Arctic. ${ }^{39}$

A salient issue which emerges for existing and future navigation of the North West passage and the Northern Sea Route by foreign flag vessels is the status of waters between the fringing islands and mainland of the Arctic coasts of Canada and Russia. Both Canada and Russia have asserted straight baseline claims around the outermost limits of the islands of their coastal archipelagos in the Arctic thereby enclosing the waters landwards of the baselines as internal waters. ${ }^{40}$ Under customary international law, foreign vessels do not have any guaranteed rights of passage in internal waters unless a straight baseline claim has had the effect of enclosing areas of water that had not previously been considered internal waters. ${ }^{41}$ In the latter case, Article $8(2)$ of the LOSC provides that foreign vessels will have rights of inno-

\footnotetext{
${ }^{37}$ Rothwell, above n. 11, 182.

${ }^{38}$ Potts et al., above n. 151; Rayfuse, above n. 3, 4 notes that "There are three areas of high seas in the Arctic: the central Arctic Ocean, the Barents Sea 'Loophole and the Norwegian Sea 'Banana Hole."

39 A.G. Oude-Elferink, "Arctic Maritime Delimitations: The preponderance of similarities with other regions" in The Law of the Sea and Polar Maritime Delimitation ed. A.G. OudeElferink and D.R. Rothwell (The Hague: Kluwer Law International, 2001), 179-199; Potts et al., above n. 8, 159 .

${ }^{40}$ Rothwell, above n. 11, 184-187.

${ }^{41}$ D.P. O'Connell (ed. I.A. Shearer), The International Law of the Sea Vol. II (Oxford: Clarendon Press, 1984), 848.
} 
cent passage through those waters. Innocent passage is a relatively restricted form of navigation in which vessels must exercise continuous and expeditious passage which is not prejudicial to the peace, good order or security of the coastal State. ${ }^{42}$ The determination of the types of activities which constitute non innocent passage is left largely to the coastal State but Article 19(2) of the LOSC has given greater clarity to the range of activities which States consider to be prejudicial to the peace good order or security of the coastal State. An additional restrictive aspect of the right of innocent passage is the power of the coastal State under Article 25(3) of the LOSC to suspend temporarily in specified areas of its territorial sea the innocent passage of foreign vessels, without discrimination in form or fact among foreign ships, if such suspension is essential for the protection of its security.

The straight baseline claims of both Canada and Russia in the North West Passage and Northern Sea Route areas have been disputed by other States, particularly the USA which maintains that the waters between the fringing islands and the mainland of Canada and Russia should be characterised as straits used for international navigation in which a guaranteed right of transit passage exists for all foreign vessels. ${ }^{43}$ Under Article 38 of the LOSC foreign vessels may exercise freedom of navigation solely for the purpose of continuous and expeditious transit of a strait used or international navigation between one part of the high seas and an exclusive economic zone and another part of the high seas or exclusive economic zone. Transit passage cannot be suspended by the coastal State although it is subject to compliance with generally accepted international regulations, procedures and practices for safety at sea and the prevention, reduction and control of pollution from ships. ${ }^{44}$ Neither Canada nor Russia has shown any inclination to resile from their straight baseline claims in the Arctic making this a potential source of confrontation as foreign shipping increases and attempts to exercise navigational rights in the North West Passage and Northern Sea Route on a more regular basis. ${ }^{45}$

In areas of Arctic waters beyond the outer limit of the coastal States' territorial seas, foreign vessels have freedom of navigation in both the exclusive economic zones of coastal States and in high seas areas beyond the 200 nautical mile limit of the coastal States exclusive economic zone. ${ }^{46}$ This is a much more liberal form of passage than innocent passage and cannot be suspended

\footnotetext{
${ }^{42}$ LOSC, Article 19(1).

${ }^{43}$ Kraska, above n. 3, 258; Rothwell, above n. 11, 194-195.

${ }^{44}$ LOSC, Articles 39(2) (a) and (b) and 44.

${ }^{45}$ Pharand, above n. 12, 69; Rothwell, above n. 11, 186-187.

${ }^{46}$ LOSC, Articles 58(1) and 87(1).
} 
by the coastal State in its exclusive economic zone but it must nevertheless be exercised with due regard to the rights and duties of the coastal State and in accordance with its laws particularly with regard to resource exploitation and protection and preservation of the marine environment. ${ }^{47}$ On the high seas, freedom of navigation must be exercised with due regard for the interest of other flag States in their exercise of the freedom of the high seas. ${ }^{48}$ The area of high seas in the Arctic has decreased with the assertion of exclusive economic zone claims by the Arctic states and is now completely encircled by these zones. ${ }^{49}$ The enclave nature of these waters has led some commentators to propose that they should be subject to the control of the Arctic States rather than being high seas areas but these claims have little validity under the LOSC or customary international law with its strong emphasis on freedom of the high seas and the exclusivity of flag State jurisdiction. ${ }^{50}$

Under the LOSC, coastal States have unilateral rights to prescribe and enforce certain laws and regulations concerning the passage of foreign vessels through their offshore zones relating to the protection and preservation of the marine environment and safety of navigation. Beyond the territorial sea, these laws must conform to generally accepted international rules or standards such as those contained in international instruments including the International Convention for the Prevention of Pollution from Ships (MARPOL 73/78), the London Convention and Protocol, the Anti Fouling Convention and the Ballast Water Convention..$^{51}$ In internal waters, the prescription and enforcement of laws and regulations concerning safety of navigation and protection and preservation of the marine environment is a matter for the coastal State and is not regulated by international law with the only concession to the interests of foreign flag States being that the coastal State shall give due publicity to these laws and regulations and notify them to the competent international Organisation. ${ }^{52}$ In territorial seas, Article 21 of the LOSC provides that the coastal State may adopt laws and regulations relating to innocent passage in respect of safety of navigation, the regulation of maritime traffic, the preservation of the environment and pollution control. The only area in which these laws must comply with international regulations and standards is in relation to the design, construction, manning or equip-

\footnotetext{
${ }^{47}$ Ibid., Article 58(3).

${ }^{48}$ Ibid., Article 87(2).

${ }^{49}$ See Rayfuse, above n. 38.

${ }^{50}$ Timo Koivurova, "Alternatives for an Arctic Treaty - Evaluation and a New Proposal" RECIEL 17(1) (2008): 14-26; Rayfuse, above n. 38, 10-11 discusses the lack of political appetite in the global community for an Arctic Treaty involving only the five Arctic States.

${ }^{51}$ LOSC, Article 211(5).

${ }^{52}$ Ibid., Article 211(3).
} 
ment of foreign ships. ${ }^{53}$ Where there are clear grounds for believing that a foreign vessel navigating in the territorial sea has violated coastal state laws for the prevention reduction and control of pollution from vessels, adopted in accordance with the LOSC, these laws may be enforced by the coastal State against all non sovereign immune vessels. ${ }^{54}$ Enforcement measures may include physical inspection of the vessel, detention and institution of proceedings. ${ }^{55}$

In its exclusive economic zone, the coastal State has jurisdiction over the protection and preservation of the marine environment but its prescriptive powers are limited to giving effect to generally accepted international rules and standards on marine pollution..$^{56}$ Recognising flag State interests in freedom of navigation, the LOSC provides for a graduated scale of coastal State enforcement against foreign vessels in the exclusive economic zone of applicable international rules and standards on vessel source pollution or laws and regulations of that State giving effect to those rules and standards. ${ }^{57}$ This begins with a requirement for the vessel to give information where there is a clear belief that a violation has occurred, escalates to physical inspection where the violation has resulted in a substantial discharge causing or threatening significant pollution of the marine environment, and culminates with a power to detain and institute proceedings where the discharge has caused major damage or threat of major damage to the coastline or related interests of the coastal State..$^{58}$ Under Article 211(6) of the LOSC, a coastal State may also designate special areas within its exclusive economic zone where the adoption of special mandatory measures for the prevention of pollution from vessels is required after consultation with the competent international Organisation. While all these regulatory powers may be available to individual coastal States under the LOSC, their exercise may be open to challenge where they are expressed to apply to areas of ocean space in which disputes exist between the coastal State and transiting flag States as to the status of the waters.

A significant omission from this catalogue of prescription and enforcement powers for protection and preservation of the marine environment are regional powers to prescribe and enforce laws and regulations applicable to marine areas beyond national jurisdiction. Enforcement of international rules and standards on vessel source pollution such as those contained in

\footnotetext{
${ }^{53}$ Ibid., Article 21(2).

${ }^{54}$ Ibid., Article 220(2).

${ }^{55}$ Ibid.

${ }^{56}$ Ibid., Article 211(5).

${ }^{57}$ Ibid., Article 220(5).

${ }^{58}$ Ibid.
} 
the International Convention for the Prevention of Pollution from Ships (MARPOL 73/78) $)^{59}$ and the Convention on Prevention of Marine Pollution by Dumping of Wastes and Other Matter (London Convention) ${ }^{60}$ and its 1996 Protocol $^{61}$ in high seas areas is almost entirely dependent on individual flag State responsibility. This gap in the LOSC regulatory framework for protecting the marine environment and the generally unilateral nature of prescriptive and enforcement powers of coastal States, suggests that a collaborative process with other States in the international community to establish international rules and standards for safety of navigation and protection of the marine environment which apply to both transboundary and high seas areas in Arctic waters may provide the Arctic States with their best opportunity to develop a comprehensive plan to mitigate the adverse impacts of increased shipping on the whole of the Arctic marine environment. Arctic States have already collaborated in developing rules for navigation through ice covered areas under their jurisdiction through the IMO. ${ }^{62}$ The changing marine environment in Arctic waters may make further cooperation imperative in developing suitable protective measures to avert the risks associated with a higher shipping density in transboundary and high seas areas of the Arctic.

\section{Enhancing Legal and Regulatory Structures to Lessen the Adverse Impacts of Increased Shipping Transits on the Arctic Marine Environment}

\section{a. IMO Measures - Particularly Sensitive Sea Areas}

Under the Revised Guidelines on Particularly Sensitive Sea Areas (Revised PSSA Guidelines) ${ }^{63}$ the IMO is able to assess areas of ocean space both within

${ }^{59}$ International Convention for the Prevention of Pollution from Ships (as amended by the 1978 Protocol), opened for signature 1 June 1978, 1340 UNTS 61 (Annex I entered into force 2 October 1983; Annex II entered into force 6 April 1987; Annex III entered into force 1 July 1992; Annex IV entered into force 27 September 2003; Annex V entered into force 31 December 1988; Annex VI entered into force 19 May 2005) (MARPOL 73/78).

${ }^{60}$ Convention on the Prevention of Marine Pollution by Dumping of Wastes and Other Matter, opened for signature 29 December 1972, 11 ILM 12941973 (entered into force 30 August 1975).

${ }^{61}$ Protocol to the Convention on the Prevention of Marine Pollution by Dumping of Wastes and Other Matter, opened for signature 7 November 1996, 36 ILM 11997 (entered into force 24 March 2006).

${ }^{62}$ Jensen, above n. 2, 107; see also Guidelines for Ships Operating in Arctic Ice-Covered Waters, IMO Doc. MSC/Circ.1056MEPC/Circ.399 (23 December 2002).

${ }^{63}$ Revised Guidelines for the Identification and Designation of Particularly Sensitive Sea Areas, IMO Doc. A 24/Res.982 (6 February 2006). 
and beyond the territorial sea of member States to determine whether they meet the criteria for special protective measures applicable to international shipping. The concept of protecting an area of the sea from harmful shipping activities for its intrinsic environmental values has had a long gestation in the IMO and is still evolving as an environmental protection tool. In order to clarify the purpose and scope of the PSSA concept, the Marine Environmental Protection Committee (MEPC) decided to revise the original PSSA Guidelines in 1999 and to de-link them from the MARPOL Special Areas Guidelines. ${ }^{64} \mathrm{New}$ Guidelines for the Identification and Designation of PSSAs were adopted in IMO Assembly Resolution A.927(22) of November 2001 and then the Revised PSSA Guidelines were adopted in IMO Assembly Resolution A.982(24) of December 2005. The Revised PSSA Guidelines include a number of clarifications to provide a better understanding of the purpose and scope of the PSSA concept and to strengthen certain aspects and procedures for the identification and designation of PSSAs and the adoption of associated protective measures. ${ }^{65}$ They place particular emphasis on ensuring that in the process of designation, all interests, including those of the coastal State, flag State and the environmental and shipping communities, are thoroughly considered on the basis of relevant scientific, technical, economic and environmental information regarding the area at risk from international shipping activities. ${ }^{66}$ The definition of PSSA is almost identical to that in the original PSSA guidelines but it specifies that the special protection provided through action by the IMO is because the area may be vulnerable to damage by 'international shipping activities' rather than the broader term 'maritime activities' which was used in the original PSSA guidelines. ${ }^{67}$

\section{b. Geographic Scope of PSSAs}

An application for designation of a PSSA may be submitted by a member Government or two or more member Governments having a common interest in a particular area. ${ }^{68}$ The criteria for designation of a PSSA apply to areas both within and beyond the territorial sea and can be used by IMO to designate PSSAs beyond the territorial sea with a view to adoption of international protective measures regarding pollution and other damage caused

\footnotetext{
${ }^{64}$ J. Ashley Roach, "Particularly Sensitive Sea Areas: Current Developments" in The Stockholm Declaration and the Law of the Marine Environment ed. Myron H. Nordquist, John Norton Moore and Said Mahmoudi (The Hague: Kluwer Law International, 2003), 313.

${ }^{65}$ Revised PSSA Guidelines, paragraph 1.1.

${ }^{66} \mathrm{Ibid}$., paragraph 1.4 .2 .

${ }^{67}$ Ibid., paragraph 1.2 .

${ }^{68}$ Ibid., paragraph 3.1.
} 
by ships. ${ }^{69}$ The unlimited geographical scope of the Revised PSSA Guidelines allows for one or more member Governments to apply for designation of a transboundary area of ocean space which is vulnerable to damage by international shipping activities as a PSSA. Theoretically two or more member Governments in proximity to an area of high seas which is vulnerable to damage from international shipping activities may also apply for a PSSA designation for that area however implementation and enforcement of that PSSA designation would then depend on individual flag State compliance.

\section{c. Criteria for Designation of a PSSA and their Potential Application to Arctic Waters}

The Revised PSSA Guidelines specify that identification of a PSSA and the adoption of associated protective measures requires consideration of three integral components: the particular attributes of the proposed area, the vulnerability of such an area to damage by international shipping activities and the availability of associated protective measures within the competence of IMO to prevent, reduce or eliminate risks from these shipping activities. ${ }^{70}$ An application for designation under the Revised PSSA Guidelines must meet at least one of the ecological, social, cultural, economic, scientific and educational criteria listed in the Guidelines. ${ }^{71}$ Some of these criteria would have particular applicability to Arctic waters. Under ecological criteria, the criterion of "uniqueness or rarity" which applies to habitats of rare, threatened or endangered species that occur in only one area could include the habitats of Arctic mammals such as the polar bear, ringed and northern fur seals and Arctic cetaceans including the bowhead and beluga whales and the Narwhal. ${ }^{72}$ Likewise the criterion of "representativeness" which refers to "an area that is an outstanding and illustrative example of specific biodiversity, ecosystems, ecological or physiographic processes or community or habitat types" could also apply to endemic Arctic species and their habitats. ${ }^{73}$ The critical habitat criterion which refers to "a sea area that may be essential for the survival, function or recovery of fish stocks or rare or endangered marine species" is relevant for some Arctic fish species which frequently include slow growing deep sea fisheries of low fecundity. ${ }^{74}$ The habitats of these species and their associated marine ecosystems could also fall under the scien-

${ }^{69}$ Ibid., paragraph 4.3 .

${ }^{70}$ Ibid., paragraph 1.5 .

${ }^{71} \mathrm{Ibid}$., paragraph 4.4 .

${ }^{72}$ Ibid., paragraph 4.4.1; Clarke et al., above n. 16, 10; Rosentrater et al., above n. 16, 104-105.

${ }^{73} \mathrm{Ibid}$., paragraph 4.4 .2 .

${ }^{74} \mathrm{Ibid}$., paragraph 4.4.4; Rosentrater et al., above n. 16, 103-104. 
tific criterion of research which is described in the Revised PSSA Guidelines as an area of high scientific interest. ${ }^{75}$ The substantial reliance of indigenous Arctic inhabitants on subsistence fishing and whaling would fulfil the social or economic dependency criterion for a PSSA designation which refers to an area where the environmental quality and the use of living marine resources are of particular social or economic importance to the population. ${ }^{76}$

The risk to the area from international shipping activities must also be addressed in a PSSA designation proposal. Factors mentioned in the Revised PSSA Guidelines which could be relevant to Arctic waters, are the types and quantities of substances carried by international shipping in the area which would be harmful if released into the sea and the meteorological hydrographic and oceanographic characteristics of Arctic waters such as wind strength, water depth and ice cover which might increase the risk of structural failure in ships. ${ }^{77}$ The risks and operational factors associated with increased volume or concentration of shipping traffic and with particular types of vessels such as bulk carriers are also relevant considerations under the Revised PSSA Guidelines. ${ }^{78}$ A proposal for designation of Arctic waters as a PSSA would need to incorporate detailed analysis of the heightened risk of illegal vessel source discharges of oily waste, sewage, garbage and other hazardous substances from increased shipping transits and their potential impact on the Arctic marine environment. Other risk assessments might include the potentially adverse impacts of ballast water exchange in the area due to the introduction of alien species which would compete with and prey on endemic Arctic species and the greater risk of maritime casualties such as grounding and collisions with the higher volume of shipping traffic. ${ }^{79}$

A key difference between the Revised PSSA Guidelines and the Original PSSA Guidelines is the requirement in the Revised Guidelines to specify at least one associated protective measure already available under an IMO instrument or if not to set forth the steps the proposing member Government has taken or will take to have the measure approved or adopted by the IMO pursuant to an identified legal basis. ${ }^{80}$ This requirement does not apply to PSSAs where IMO protective measures such as vessel source discharge restrictions under MARPOL 73/78 are already in place but the application must show how the area is being protected ${ }^{81} \mathrm{~A}$ range of protective measures

\footnotetext{
${ }^{75}$ Ibid., paragraph 4.4.15.

${ }^{76}$ Ibid., paragraphs 4.4.12 and 4.4.13.

77 Ibid., paragraphs 5.1.4, 5.1.5, 5.1.6 and 5.1.7.

${ }^{78}$ Ibid., paragraphs 5.1.1, 5.1.2 and 5.1.3.

${ }^{79}$ Clarke et al., above n. 16, 12; Rosentrater et al., above n. 16, 99.

${ }^{80}$ Revised PSSA Guidelines, paragraph 7.1.

${ }^{81}$ Ibid., paragraph 7.2.
} 
that could be proposed for Arctic waters subject to increased international shipping activity might include strict restrictions on vessel source discharge, steering ships away from the most sensitive habitats by the prescription of specific shipping channels or areas to be avoided, more intense surveillance and monitoring of shipping activity through ships reporting services and vessel traffic services to prevent groundings and collisions, early notification of ships in distress and the prescription of high quality construction, design, equipment and crewing standards to afford the maximum protection for the sensitive Arctic marine environment. Roach comments that the requirement to specify associated protective measures within the competence of IMO has provided a legal basis on which to provide tailored protection to PSSAs and removed a basic concern that mere designation of a marine area worthy of protection could lead to encroachment on navigational rights and freedoms. ${ }^{82}$ Tying the designation of a PSSA to established processes for considering ships routing measures under the International Convention for the Safety of Life at Sea Convention (SOLAS Convention) ${ }^{83}$ and established vessel source discharge restrictions under MARPOL 73/78 have enabled the interests of the shipping industry to be considered in a binding legal framework. The revised PSSA Guidelines also leave open the possibility of the IMO developing and adopting new measures designed to protect specific sea areas from the adverse impacts of international shipping. ${ }^{84}$

\section{d. Implementation and Enforcement of PSSAs and Associated Protective Measures}

Implementation of the protective measures associated with a PSSA designation is dependent on IMO member States enacting the relevant laws and regulations in marine areas within their national jurisdiction and where protective measures are already contained in treaty provisions such as MARPOL 73/78 and the SOLAS Convention, on flag States complying with those measures. The Revised PSSA Guidelines prescribe that member Governments should ensure that any associated protective measures are implemented in accordance with international law as reflected in the LOSC and that ships flying their flag comply with the associated protective measures adopted in connection with the designated PSSA.$^{85}$ If they receive reports of alleged vio-

${ }^{82}$ Roach, above n. 64, 313

${ }^{83}$ International Convention for the Safety of Life at Sea, opened for signature 1 November 19741980 UKTS 46 (entered into force 25 May 1980) (SOLAS Convention).

${ }^{84}$ Revised PSSA Guidelines, paragraph 7.5.2.3(ii).

${ }^{85}$ Ibid., paragraphs 9.2 and 9.3 . 
lations of protective measures endorsed under the Revised PSSA Guidelines by ships flying their flag, member States must provide the reporting Government with details of any action taken. ${ }^{86}$ Under the Revised PSSA Guidelines there is no specific provision for collaborative monitoring of compliance or enforcement of protective measures connected with a PSSA designation. Development of cooperative maritime surveillance and enforcement arrangements in transboundary or high seas areas of the Arctic may contribute to more effective implementation of such measures if they are introduced in Arctic waters.

State Practice in Designating Transboundary PSSAs

Recent proposals for PSSAs in the IMO have included some designations which cover transboundary sea areas and at least at the consultation stage within IMO, have reflected a more integrated approach to developing protective shipping measures which result in harmonised implementation across marine areas within the jurisdiction of the proponents. PSSA designations in the Baltic Sea, Wadden Sea, Western European waters and the Torres Strait all provide models for consideration in developing a proposal for PSSA designation in Arctic waters. ${ }^{87}$ The development of the first joint proposal for a PSSA in the Wadden Sea adjacent to the North Sea illustrates the importance of careful analysis of the nature of marine traffic in the area including cargo types, crewing, range, purpose of activities and traffic flow and of consulting with stakeholders affected by the proposed protective measures to gauge the level of support for any new measures. In the Wadden Sea case a feasibility study was conducted prior to submitting the PSSA proposal which examined existing protective measures and surveyed a variety of stakeholders including the shipping industry, the energy sector, local users and non government organisations to assess their views on multiple options for additional

${ }^{86}$ Ibid.

${ }^{87}$ IMO, Particularly Sensitive Sea Areas, http://www.imo/org/home.asp, (accessed 24 August 2008) lists twelve PSSAs of which four were joint proposals: The Great Barrier Reef, Australia (1990); the Sabana Camaguey Archipelago, Cuba (1997); Malpelo Island, Colombia (2002); the sea around the Florida Keys, United States (2002); the Wadden Sea, Denmark, Germany, the Netherlands (2002); Paracas National Reserve, Peru (2003); Western European Waters, Belgium, United Kingdom, Ireland, France, Spain and Portugal (2004); extension of the existing Great Barrier Reef PSSA to include the Torres Strait, Australia and Papua New Guinea (2005); Canary Islands, Spain (2005); the Galapagos Archipelago, Ecuador (2005); the Baltic Sea area, Denmark, Estonia, Finland, Germany, Latvia, Lithuania, Poland and Sweden (2005); the Papahanaumokuakea Marine National Monument, United States (2007). 
protective measures ${ }^{88}$ In particular, the need to introduce extra protective measures affecting shipping in the Wadden Sea, which was already a MARPOL Special Area prohibiting the discharge of oil, oily waters and garbage under MARPOL Annexes I and V by ships of certain tonnage, was assessed. The study concluded that a limited package of additional associated protective measures which could not be introduced unilaterally by the individual coastal States involved in the proposal, Germany, Denmark and the Netherlands should be considered for inclusion in the proposal. ${ }^{89}$ These were a Wadden Sea Vessel Traffic Management System which would confer the ability to identify areas of shipping congestion and if necessary to re-route shipping, mandatory reporting for certain classes of vessels including older smaller vessels not fitted with automatic identification systems to reduce the risk of marine accidents, and compulsory pilotage for large ships using a deep water route in the Wadden Sea which have little or no experience of the Wadden Sea conditions. ${ }^{90}$ The proposal for PSSA designation was made on the basis of these recommendations and endorsed by the IMO in 2002.91 A similarly comprehensive analysis for changing Arctic waters would take time to prepare but would optimise the likelihood of support for a PSSA designation and associated protective measures from the shipping industry and other users of the Arctic sea routes. The Wadden Sea experience also demonstrates the need for ongoing analysis of the suitability of ships routing measures in specific sea areas and the need to adjust the package of measures to changing conditions.

The Baltic Sea which was the subject of a PSSA designation in 2005 could be viewed as sharing some attributes with future Arctic waters in which the North West Passage and the Northern Sea Route have become more navigable and are subject to a higher volume and diversity of shipping traffic. ${ }^{92}$ The Baltic Sea, in common with the coastal archipelagos of the North West Passage and the Northern Sea Route, has multiple islands, narrow straits and periodic ice cover. Inherently risky shipping activities such as oil transpor-

${ }^{88}$ Maritime Research Centre, Faculty of Technology, Southampton Institution, PSSA Wadden Sea Feasibility Study: Advice to Trilateral Wadden Sea Cooperation. Final Report, (May 2001), <http:www.waddensea-secretariat.org/news/documents/pssa/PSSA-report.pdf >, (accessed 24 August 2008).

${ }^{89}$ Ibid., paragraph 7.10.7.

${ }^{90}$ Ibid., paragraph 7.9 .7

${ }^{91}$ The Wadden Sea PSSA designation was adopted by the IMO Marine Environment Protection Committee (MEPC) in MEPC Resolution 101/48 of 11 October 2002 contained in IMO Doc. MEPC 48/21, Annex 5.

${ }_{92}$ The IMO MEPC approved the designation of the Baltic Sea PSSA excluding Russian waters at its 51st Session from 29 March to 2 April 2004. 
tation and bulk tankers carrying other hazardous cargoes are conducted in close proximity to sensitive marine habitats for mammals such as the Baltic ringed seals and harbour porpoises and important migratory routes for seabirds such as black guillemots, waterfowl and geese. ${ }^{93} \mathrm{~A}$ suite of protective measures have been developed by the Baltic States in conjunction with IMO member States to reduce the risks posed by the considerable maritime traffic transiting their collective offshore areas. These include new traffic separation schemes, a recommended deep water route and a recommendation to use pilotage when navigating from the North Sea into the entrances to the Baltic Sea for every ship with a draught of 11 metres or more and for ships carrying hazardous cargo. ${ }^{94}$

The politically sensitive nature of PSSA designations which cover large areas of sea crossing State boundaries such as the Western European PSSA designation and those which are centred on key international waterways such as the Torres Strait cannot be underestimated. In both these designations, proposed and endorsed protective measures have attracted criticism on the basis that sufficient justification has not been advanced for implementing the measures across the whole of a particular sea area and that they unduly restrict the navigational rights of transiting vessels under the LOSC. The Western European waters PSSA designation proposal covered an expansive sea area which included the western coasts of the United Kingdom, Ireland, Belgium, France, Spain and Portugal from the Shetland Islands in the north to Cape Vicente in the south including the English Channel and its approaches. ${ }^{95}$ The area in question was already subject to a complex array of ships routing measures encompassing fourteen traffic separation schemes, two deep water routes, seven areas to be avoided and four mandatory ship reporting systems..$^{96}$ The six applicant States proposed two further protective measures which would prohibit the carriage of heavy grades of oil through the entire PSSA in vessels of more than $600 \mathrm{dwt}$ except in double hull tankers which would also be obliged to comply with a mandatory reporting obligation with a 48 hour notice period. ${ }^{97}$ After concerns raised by some IMO member States delegations as to the extent of the area covered by the proposed PSSA designation and the lack of a basis under international law for

${ }^{93}$ Helsinki Commission, Baltic News. Sensitive Baltic Sea areas now protected from shipping activities, http://www.helcom.fi/press_office/news_baltic/en_GB/BalticNews5952424 (accessed 24 August 2008).

${ }^{94}$ Ibid.

${ }^{95}$ Julian Roberts, Martin Tsamenyi, Tim Workman and Lindy Johnson, "The Western European PSSA Proposal: a politically sensitive sea area" Marine Policy 29 (2005): 434.

${ }^{96}$ Ibid.

${ }^{97}$ Ibid., 435. 
denying the innocent passage and freedom of navigation of single hulled vessels carrying heavy grades of oil in the proposed PSSA area the first additional protective measure was withdrawn leaving only the mandatory reporting requirement. ${ }^{98}$

The circumstances of the Western European PSSA designation process highlight the importance of being able to justify the application of the proposed protective measures across the whole of the area to be designated and the necessity of preserving established navigational rights within an environmentally sustainable context. Any proposal for global endorsement of protective measures in the extensive area covered by Arctic waters and the increasingly important waterways represented by the North West Passage and the Northern Sea Route would require intensive analysis and stakeholder consultation to strike the appropriate balance between effective protective measures and navigational rights which are consistent with law of the sea principles.

The implementation of the Torres Strait PSSA designation proposed by Australia and Papua New Guinea (PNG) also demonstrates the delicate balance involved in developing appropriate environmental safeguards for vessels transiting a particularly sensitive sea area and preserving their established passage rights under international law. The environmental conditions of Torres Strait decisively fulfil many of the criteria for PSSA designation under the Revised PSSA Guidelines. The Strait lies to the north and east of Cape York and separates Australia and PNG. It is approximately 150 kilometres (90 nautical miles) wide and 200 kilometres (150 nautical miles) long although useable routes for large commercial vessels are limited to the Prince of Wales Channel and the Great North East Channel..$^{99}$ Passage through these channels is navigationally demanding with limited under keel clearance for deep draught vessels, strong tidal streams due to the meeting of the Pacific and Indian Oceans and low visibility due to the monsoonal climate. ${ }^{100}$ The strait hosts critical habitats for many vulnerable species including dugongs and green and flat back turtles. ${ }^{101}$ The several thousand Torres Strait islanders are ethnically distinct and are heavily dependent on the continuing health of the surrounding marine environment and its resources for their liveli-

\footnotetext{
98 Ibid., 437.

${ }^{99}$ Stuart B. Kaye, The Torres Strait (Dordrecht: Martinus Nijhoff Publishers, 1997), 1 and 14.

100 Adam McCarthy, "Protecting the Environment and Promoting Safe Navigation: Compulsory Pilotage in the Torres Strait" International and Humanitarian Law Resources 6 (28 June 2007) <http:www.worldlii.org/int/journals/IHLRes/2007/6.html>, (accessed 24 August 2008).

${ }^{101}$ Ibid.
} 
hood. ${ }^{102}$ The Torres Strait is used principally by large commercial vessels trading between ports in southern Asia and NZ, South America, PNG and Pacific Island countries with approximately 3000 vessels transiting the Torres Strait annually. ${ }^{103}$ Due to the low rate of water exchange in and out of Torres Strait, a major marine pollution incident could have profound and deleterious impacts on the marine species, habitats, ecosystems and indigenous inhabitants of the Strait. Maritime casualties such as groundings or collisions in the Torres Strait could also obstruct shipping transits because of the confined nature of the only navigable shipping channels. ${ }^{104}$

To mitigate the risks posed by shipping to the Torres Strait the Australian Government implemented a recommended system of voluntary pilotage in the Torres Strait in 1991 following consultation with and endorsement by IMO.$^{105}$ The proportion of uptake of pilots on transiting vessels declined over time from 70 percent in 1995 to 35 percent in 2003. ${ }^{106}$ As a result Australia and PNG proposed that the Torres Strait be designated as a PSSA with an associated protective measure of compulsory pilotage in the recommended navigation channels. ${ }^{107}$ The IMO Resolution of the Marine Environment Protection Committee designating the Torres Strait as a PSSA was adopted on 22 July 2005 and recommended that member Governments recognise the need for effective protection of the Torres Strait region and inform ships flying their flags that they should act in accordance with Australia's system of pilotage for merchant ships 70 metres in length or for oil, chemical and gas tankers irrespective of size when navigating...the Torres Strait and the Great North East Channel between Booby Island and Bramble Cay. ${ }^{108}$ The language of the Resolution included the phrase 'Australia's pilotage system' which was a reference to the compulsory pilotage system in the Great Barrier Reef. ${ }^{109}$ To implement the IMO Resolution, Australia passed amendments to its Navigation Act, 1912 making it an offence to navigate in designated pilotage areas without a licensed pilot and allowing regulations to specify areas for which pilotage was compulsory. ${ }^{110}$ These amendments, which entered into force in

102 Kaye, above n. 99, 61; McCarthy, above n. 100.

${ }^{103}$ Kaye, above n. 99, 14; McCarthy, above n. 100.

104 McCarthy, above n. 100.

${ }^{105}$ Ibid.

${ }^{106} \mathrm{Ibid}$.

107 Extension of Existing Great Barrier Reef PSSA to include the Torres Strait Region submitted by Australia and Papua New Guinea, MEPC, 49th Session, IMO Doc MEPC 49/8, 10 April 2003.

${ }^{108}$ IMO Resolution MEPC 133(53) of 22 July 2005, IMO Doc. MEPC 53/24/Add.2, Annex 21.

109 McCarthy, above n. 100.

${ }_{110}$ Ibid. 
October 2006, provided significant financial penalties for a master or owner of a vessel who failed to comply with the pilotage requirements but did not include provision for Australian authorities to stop or board vessels transiting the Torres Strait without a pilot. ${ }^{111}$ Instead they provided for Australian Government authorities to record an offence by the owner or master of the non-compliant vessel and then to seek to enforce the penalty when the vessel entered a port in Australia. ${ }^{112}$

Since the introduction of the amendments there has been no recorded non-compliance but some States, in particular the US and Singapore have objected to the Australian legislation and questioned its consistency with the obligation not to hamper, deny or impair transit passage under Article 44 of the LOSC. ${ }^{113}$ The criticisms directed towards Australia's implementation of the compulsory pilotage scheme in the Torres Strait provide a portent for the Arctic States in any future development of a PSSA proposal for Arctic waters of objections which may be raised by other States to financial penalties imposed on vessels exercising transit passage in straits used for international navigation as a result of non compliance with protective measures implemented at the national level, even though they are only imposed subsequent to their passage being completed. These objections reflect the concerns on the part of flag States to resist any perceived erosion of navigational rights through the actions of coastal States in implementing environmental safeguards which disproportionately restrict passage rights.

\section{e. IMO Measures - MARPOL Special Areas}

As a precursor to or in conjunction with a PSSA designation the Arctic States could examine the designation of Special Areas under the provisions of MARPOL 73/78 in Arctic waters which become more vulnerable to marine pollution from increased vessel traffic through the Arctic sea routes. The concept of special areas in MARPOL 73/78 recognises the existence of oceanographical, ecological and traffic conditions in a particular area of the sea which justify a complete prohibition on oil and other vessel discharges except in very limited circumstances. ${ }^{114}$ A special area may encompass the maritime zones

\footnotetext{
${ }^{111}$ Ibid.

112 Ibid.

${ }^{113}$ Ibid., Robert C. Beckman, "PSSAs and Transit Passage-Australia's Pilotage System in the Torres Strait Challenges the IMO and UNCLOS" Ocean Development and International Law 38 (2007): 326.

114 MARPOL 73/78, Annex I, Regulation 1(10).
} 
of several States or even a whole enclosed or semi-enclosed sea. ${ }^{115}$ In support of a proposal for designation of a particular area of the sea as a special area under Annexes I, II or V of MARPOL 73/78, States must provide information on its oceanographic conditions, ecological conditions and vessel traffic characteristics. ${ }^{116}$ Under the criterion of oceanographic conditions, evidence must be provided that the area has conditions which may cause the concentration or retention of harmful substances in the waters or sediments such as particular circulation patterns, long residence time caused by low flushing rates, extreme ice state or adverse wind conditions. ${ }^{117}$ Ecological conditions can be substantiated by evidence such as depleted, threatened or endangered species, spawning, breeding and nursery areas for important marine species and migratory routes for sea birds and marine mammals, rare and fragile ecosystems and critical habitats for marine resources including fish stocks and areas of importance for the support of large marine ecosystems. ${ }^{118} \mathrm{~A}$ proposal for a special area designation should also provide evidence that the sea area is used by ships to such an extent that the discharge of harmful substances by ships, when operating in accordance with the requirements of MARPOL 73/78 for areas other than special areas, would be unacceptable in the light of the existing oceanographic and ecological conditions in the area. ${ }^{119}$ Most of these criteria could be demonstrated in a proposal for designation of particular parts of Arctic waters as special areas. ${ }^{120}$

There are multiple special areas under Annexes I, II and V of MARPOL $73 / 78$ which provide strict controls on vessel discharge of oil, noxious liquid substances and garbage. ${ }^{121}$ These cover marine areas both within and beyond national jurisdiction. Oceanic regions of comparable environmental sensitivity to the Arctic which have declared special areas under MARPOL 73/78 Annex I on oil discharge include the Baltic Sea, North West European waters, the Mediterranean Sea and Antarctica. Special areas under Annex V

115 IMO Resolution A.927(22) of 29 November 2001, Guidelines for the Designation of Special Areas under MARPOL 73/78 and Guidelines for the Identification and Designation of Particularly Sensitive Sea Areas, Annex 1, paragraph 2.2.

116 Ibid., paragraph 2.3 .

117 Ibid., paragraph 2.4 .

${ }_{118}$ Ibid., paragraph 2.5 .

119 Ibid., paragraph 2.6 .

${ }^{120}$ Jensen, above n. 2, 108 notes that an earlier draft 'International code of safety for ships in polar waters' submitted to the IMO's sub committee on ship design and equipment at its 41 st session in 1998 was aimed among other things at designating the Arctic and Antarctic as MARPOL 73/78 special areas but was not considered to be the appropriate mechanism for this purpose; Rosentrater et al., above n. 16, 98 and 110.

${ }^{121}$ MARPOL 73/78 special areas are listed at $<\mathrm{http}$ ://www.imo.org. 
providing for strict controls on garbage disposal at sea have been established in the Baltic Sea, the North Sea and the Antarctic area south of 60 degrees south latitude. A special area under Annex II to MARPOL 73/78 providing strict controls on the discharge of noxious liquid substances has been established in the Antarctic area. A WWF report has suggested that an expansion of shipping in the Arctic as a result of climate change should be accompanied by very strict vessel source discharge restrictions by according special area status under the relevant MARPOL Annexes to these waters. ${ }^{122}$ Enforcement of special areas discharge restrictions relies primarily on individual flag State compliance although port States have formed memoranda of understanding (MOUs) to monitor and enforce compliance with MARPOL 73/78 measures including special areas. ${ }^{123}$ The establishment of port state control MOUs has ameliorated some of the laxities of flag State control. ${ }^{124}$ With increased shipping traffic in Arctic waters the establishment of a Port State MOU among the Arctic States could be a useful adjunct to flag State enforcement together with the development of Arctic port reception facilities for vessel source discharges.

\section{Conclusion}

To ensure that future shipping in changing Arctic waters exercises environmentally sustainable navigation, it would be prudent for Arctic States to instigate forward planning for a robust regulatory framework which is consistent with both law of the sea and international environmental law. Shipping disasters causing major damage to the marine environment in other parts of the world have demonstrated that the powers of coastal states to prescribe and enforce laws and regulations unilaterally for the potentially adverse impacts of increased shipping traffic under the provisions of the LOSC and other international law instruments have proven insufficient. There is now a trend in State practice for member States of the IMO to submit joint proposals for protective measures to be applied to certain classes of vessel with the potential to cause harm to environmentally sensitive areas of the sea. Parallel assessments of the likely shipping density and biodiversity protection needs in Arctic waters which are already being undertaken through the

\footnotetext{
${ }^{122}$ Rosentrater, above n. 16, 110.

${ }^{123}$ IMO, Port State Control, <http:www.imo.org/Safety/mainframe.asp?topic_id=159\&doc_ id=523>, (accessed 24 August 2008).

${ }^{124}$ Ronald P. Barston, "Port State Control: Evolving Concepts" in The Common Heritage and Emerging Challenges ed. Harry N. Scheiber (The Hague: Kluwer Law International, 2000), 87.
} 
Arctic Council and associated bodies could eventually form the basis for a feasibility study of Arctic shipping routes in environmentally sensitive areas of Arctic waters and subsequent PSSA and MARPOL special area designation proposals negotiated at a global level with member States of the IMO. The development of these measures should be a product of consultation by Arctic States which transcends the sovereignty and legal status disputes over Arctic waters. ${ }^{125}$ Joint proposals for PSSA designation in other oceanic regions with unique environmental conditions provide useful insights into the physical extent, nature of associated protective measures and balance between navigational access and environmental protection which will find acceptance in the global community. In developing a case for introducing protective measures associated with a PSSA and special areas designations it will be important to emphasise that unfettered military and strategic access to Arctic waters is preserved through passage rights provisions of LOSC and sovereign immune exemptions. Effective implementation of protective measures to avert the adverse impacts of increased shipping in the Arctic sea routes may also require collaborative enforcement measures which encompass transboundary and high seas areas and the development of a port State agreement among Arctic states to supplement flag State enforcement.

125 Andrea Charron, "Canada, the US and the North West Passage. Sovereignty to the Side" Polar Geography 29(2) (2005): 139; Kraska, above n. 2, 281-282. 
